\title{
A STUDY OF BODY WEIGHT AND MILK TRAITS OF KARADI EWES - SULAIMANI GOVERNORATE, IRAQ
}

\author{
HAMA KHAN, K. M. ${ }^{*}-$ AL-BARZINJI, Y. M. S. ${ }^{2 * *}-$ MAAROF, N. N. ${ }^{1}$ \\ ${ }^{1}$ Department of Animal Science, College of Agricultural Science, University of Sulaimani, \\ Sulaimani, Iraq \\ ${ }^{2}$ Department of Animal Resource, College of Agriculture Engineering Science, Salahaddin \\ University-Erbil, Iraq \\ *Corresponding author \\ e-mail: karwan.hamakhan@univsul.edu.iq; phone: +964-772-526-3296 \\ **Yousif.Noori@Su.Edu.Krd \\ (Received $26^{\text {th }}$ May 2019; accepted $10^{\text {th }}$ Sep 2019)
}

\begin{abstract}
This study was carried out to investigate the effect of some factors on birth weight (BW), weaning weight (WW), marketing weight (MW), average daily gain (ADG), daily milk yield (DMY), total milk yield (TMY), protein and fat percentage. A 135 ewes from three flocks used, 114 of them were lambed. The mean $\pm \mathrm{SE}$ of BW, WW, MW, ADG, DMY, TMY, protein percentage and fat percentage were $\quad 4.14 \pm 0.65, \quad 16.37 \pm 2.87, \quad 23.60 \pm 4.42, \quad 0.12 \pm 0.02, \quad 0.236 \pm 0.10, \quad 34.07 \pm 5.94 \quad \mathrm{~kg}, \quad$ and $5.33 \pm 0.62 \%$ and $5.30 \pm 12.93 \%$, respectively. All studied traits were significantly $(\mathrm{P} \leq 0.05)$ affected by flock except BW, protein and fat percentages. Month of lambing had significant effects $(\mathrm{P} \leq 0.05)$ on MW, ADG and Post daily gain. Stage of lactation had a significant effect $(P \leq 0.05)$ on daily milk yield and protein percentage. The lowest and highest BLUP values for BW, WW, MW, ADG, DMY, TMY, protein and fat percentages were $-1.6411,1.6889 \mathrm{~kg},-6.5307,10.1293 \mathrm{~kg},-9.9775,13.1725 \mathrm{~kg},-10.5293$, $10.7504 \mathrm{~kg},-31.02,7.38 \mathrm{~kg},-2.0546,2.0097 \%,-1.703,1.40 \%$ respectively. These results indicated that there are high genetic variations among animals for all above studied traits. It means that selection can play a big role in improving economical traits.
\end{abstract}

Keywords: Birth Weight, Weaning Weight, Marketing Weight, Milk Yield, BLUP, Fat \%, Protein \%

\section{Introduction}

Small ruminants (sheep and goat) are important investments in Iraq. They play a major role in strengthening the backbone of the rural economy. The Karadi sheep which comprises about $18-20 \%$ of the total sheep population to the northeastern mountain, villages and undulating dry-farming plain of Kurdistan region of Iraq (Alkass and Juma, 2005). Sheep and goat population in Kurdistan region had been estimated to be around 3,500,000 (Ahmad, 2011). Productivity of this breed is low due to the fact that animals are naturally selected for survival under suboptimal environments. Assessment of the amount of milk produced by ewes provides information for the implementation of optimum management and feeding strategies for female sheep and their lambs (Cardellino and Benson, 2002).

Many studies analyzing the factors affecting ewes' growth performance, milk yield and milk composition were reported (Al-Barzinji and Hassan, 2005; Antonič et al., 2013). The main factors were flock (Meraï et al., 2014; Everett-Hincks, et al., 2014; Rahimi et al., 2014), ewes age (Ramakrishanappa et al., 2015; Sezenler et al., 2016; Siddalingamurthy et al., 2017), sex of lamb (Al-Samarai et al., 2016; Al-Bial et al., 2016; Malik et al., 2016), month of lambing (Al-Samarai et al., 2016; Malik et al., 
2016). The effect of stage of lactation on milk yield and composition were also reported by (Kuchtik et al., 2008; Komprej et al., 2012).

In order to devise effective breeding plans for genetic improvement of Karadi ewes, information on the extent of genetic and environmental factors on performance traits is the pre-requisite. Therefore, this study was planned to generate information on the relative importance of genetic and environmental factors on the growth and milk traits of Karadi ewes in addition to estimating the Best Linear Unbiased Prediction (BLUP) for some growth and milk traits.

\section{Materials and methods}

The data were obtained from Karadi ewes in three private flocks (Fig. 1) at different location, Arbat District (Latitude, $35^{\circ} 25^{\prime}$ 14", Longitude, $45^{\circ} 03$ ' 36", W, elevation $681 \mathrm{~m}$ ), Sharazoor District (Latitude, $35^{\circ} 15^{\prime} 27^{\prime}$ ', Longitude, $45^{\circ} 42^{\prime} 21^{\prime \prime}, \mathrm{W}$, elevation

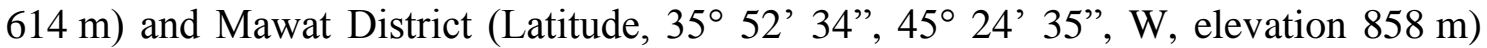
around Sulamania governorate in Kurdistan Region of Iraq (Fig. 2). All animals were apparently healthy and were fed on pasture under open field conditions. In this study, 114 ewes were utilized. At lambing ewes and lambs were identified with spray in addition to the plastic tags with numbers. Lambing date, birth weight, sex of lambs, and other relevant information were recorded. Body weights of lambs at birth and at age of 90 (Weaning weight) and 150 (Marketing weight) days, were also recorded. Milk yield was recorded monthly starting from the second week of lambing until the 150 days (less than $50 \mathrm{gm}$ milk/ewe/day) post partum using lamb-suckling technique plus hand milking (Mousa and Shetawi, 1994). Lambs were separated from dams at $7.00 \mathrm{pm}$ on the day before measuring test milk production. In the following day, lambs were weighed at 7.00 am., and left to suckle their dams until satisfaction, then reweighed and kept away from their mothers, while the residual milk in the udder of each ewe were hand milked and weighted, and the amount of milk was recorded and then multiplied by 2 to calculate the daily milk yield, which multiplied by 30 then summed to calculate the total milk yield (ICARDA and FAO, 1995). Protein \% and fat\% of milk were estimated from the milk sample monthly using Milkoscan TM minor machine (P/N 60044208 , Issue 1 GB, March 2010, FOSS Analytical, 69, Slangerupgade, DK 3400 Hillerod, Denmark).

The PROC GLM (General Linear Model) procedure in SAS programs (2010) was used to analyze the data for weights at different ages, average daily gain as well as milk yield traits. Fixed effects studies were: parity, sex of lamb, the month of birth, and age at weaning were fitted in the following model (1) and (2):

\section{Model I for weight traits}

$$
\mathrm{Y}_{\mathrm{ijklm}}=\mu+\mathrm{V}_{\mathrm{i}}+\mathrm{N}_{\mathrm{j}}+\mathrm{O}_{\mathrm{k}}+\mathrm{H}_{1}+\mathrm{E}_{\mathrm{ijklm}}
$$

where Yijklm $=$ Weights of lambs at different ages and average daily gain (ADG) of individual lambs; $\mu=$ Over all mean; $\mathrm{Vi}=$ Fixed effect of flock $(\mathrm{i}=1,2,3) ; \mathrm{Nj}=$ Fixed effect of age of dam $(j=1,2,3,4,5)$; Ok = Fixed effect of sex of lams ( $k=$ male, female); $\mathrm{Hl}=$ Fixed effect of month of lambing $(1=$ November, December, January and February $)$; Eijklm $=$ Random/error effect. 

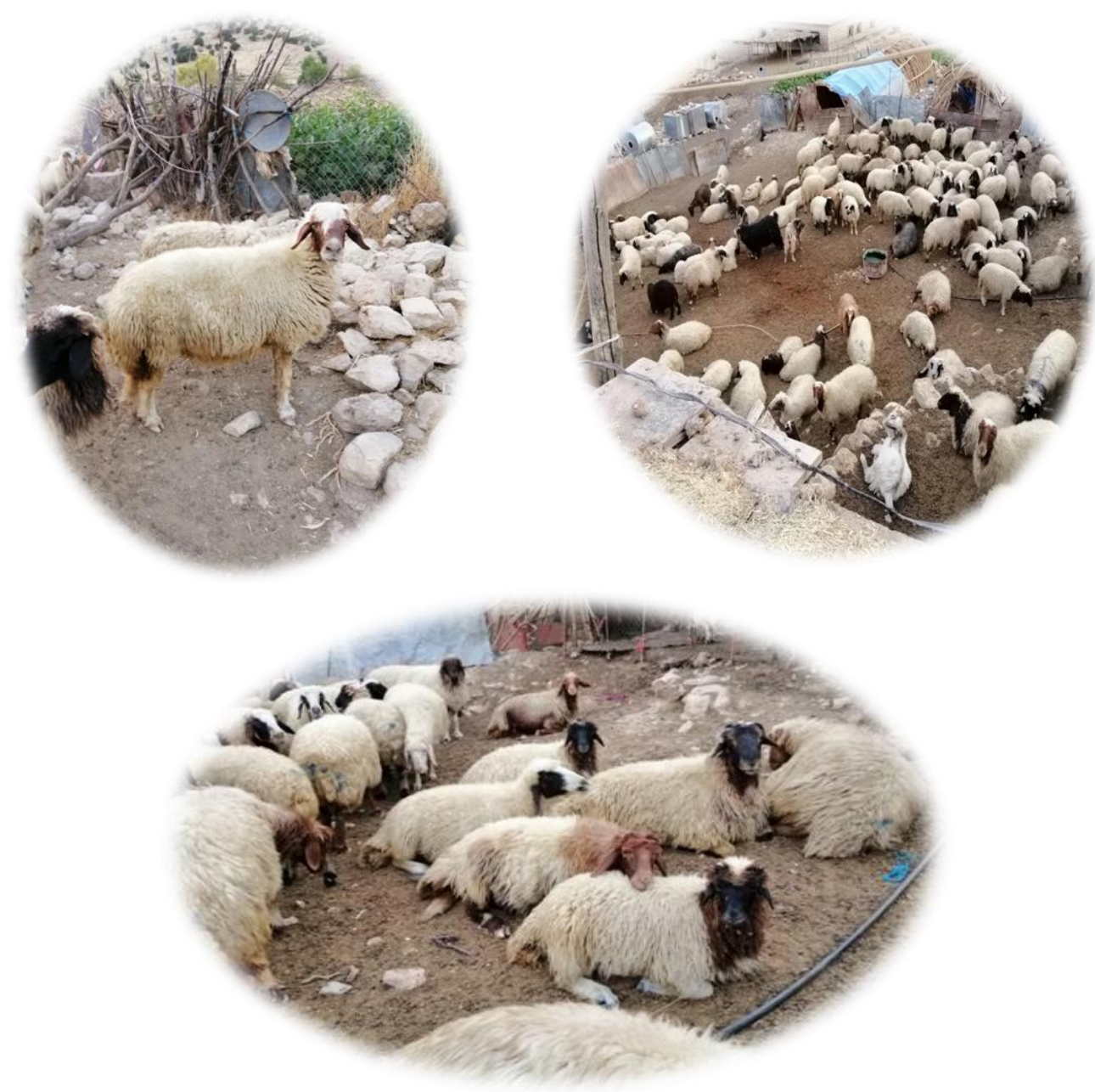

Figure 1. Sheep photo with flocks

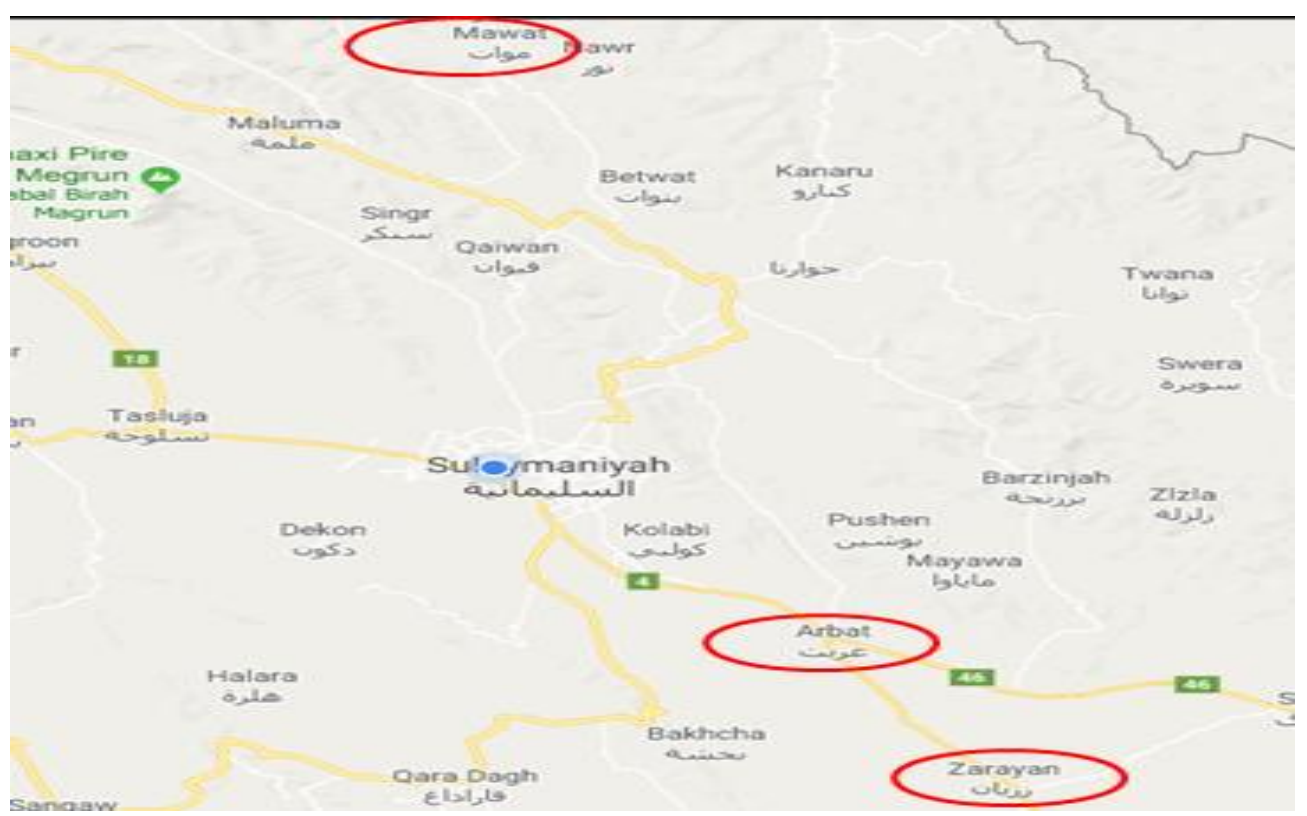

Figure 2. Study locations

APPLIED ECOLOGY AND ENVIRONMENTAL RESEARCH 17(6):14025-14038.

http://www.aloki.hu • ISSN 15891623 (Print) • ISSN 17850037 (Online)

DOI: http://dx.doi.org/10.15666/aeer/1706_1402514038

(c) 2019, ALÖKI Kft., Budapest, Hungary 


\section{Model II for milk traits}

$$
\mathrm{Y}_{\mathrm{ijklmn}}=\mu+\mathrm{Vi}+\mathrm{Nj}+\mathrm{Ok}+\mathrm{Hl}+\mathrm{Zm}+\mathrm{E}_{\mathrm{ijklmn}}
$$

The notation of the second model is similar to the first model except $\mathrm{Zm}=$ Fixed effect of stage of lactation $(\mathrm{m}=1,2,3,4,5)$.

Tukey tests used to compare between means for all traits under study because its suitable test to comparing least square means with this program. For genetics evaluation of ewes for various performance traits, Best Linear Unbiased Prediction (BLUP) procedure described by (SAS, 2010) was applied. The model used for this purpose was the Mixed Model (fixed + random effects) of (SAS, 2010) software.

\section{Results}

\section{Growth traits of Karadi lambs}

Least square means $\pm \mathrm{SE}$ of $\mathrm{BW}, \mathrm{WW}, \mathrm{MW}, \mathrm{ADG}$, pre-weaning and post weaning daily gain of the Karadi lambs are presented in Table 1. The overall means of BW, WW, MW, ADG pre-weaning and post weaning daily gain were $4.14 \pm 0.65 \mathrm{~kg}, 16.37 \pm 2.87$ $\mathrm{kg}, 23.60 \pm 4.42 \mathrm{~kg}$ and $0.12 \pm 0.02 \mathrm{~kg}, 0.13 \pm 0.02 \mathrm{~kg}$ and $0.12 \pm 0.04 \mathrm{~kg}$, respectively.

\section{Milk traits of Karadi ewes}

The least square means \pm SE of to identify the effect of fixed effects on the observed milk production performance recorded such as daily milk yield, total milk yield, protein $\%$ and fat $\%$ are given in Table 2. The overall means were $0.236 \pm 0.10 \mathrm{~kg} / \mathrm{day}, 34.07 \pm 5.94$ $\mathrm{kg} /$ day, $5.33 \pm 0.62 \%$ and $5.30 \pm 12.93 \%$ for DMY, TMY, protein $\%$ and fat $\%$ respectively.

The BLUP values of ewes for some studied traits are shown in Table 3. The lowest BLUP values for BW, WW, MW, DMY, TMY, protein\% and fat\% were -1.641, -6.530, $9.977,-10.52,-2.054,-34.20$ and $-1.703 \mathrm{~kg}$ respectively. The corresponding values of highest BLUP values were 1.688, 10.12, 13.17, 10.75, 2.009, 7.380 and $1.406 \mathrm{~kg}$.

\section{Discussion}

\section{Growth traits of Karadi lambs}

The mean of the BW $(4.14 \pm 0.65 \mathrm{~kg})$ in current study was moderately high and the birth weight have significant effect on other last weights, for that the increase this trait is very importance in sheep breeding. This result was agreement with other studies reported earlier by several investigators in different breeds of sheep (Hussain et al., 2006; Jawasreh and Khasawneh, 2007). Also the mean of WW/lamb $(16.37 \pm 2.87 \mathrm{~kg})$ and $\mathrm{MW} / \mathrm{Lamb}(23.60 \pm 4.42 \mathrm{~kg})$ were moderately high and marketing weigh determines the outcome of sheep breeders, for that increases these traits necessary in sheep breeding. The effects of flock on WW, MW, ADG pre-weaning and post weaning were significant $(\mathrm{P} \leq 0.05)$. The significant differences in weaning weight due to flock was in agreement with results obtained by Baneh et al. (2010), Tariq et al. (2011), Everett-Hincks et al. (2014) and Rahimi et al. (2014). The significant differences due to flock on ADG and pre-weaning daily gain were in agreement with resulted reported earlier by Baneh and Hafezian (2009) and Tariq et al. (2013). Flock can have a 
significant effect on body weight at different ages and average daily gain and could be attributed mainly to differences in management and environmental conditions. This results show the good management and conditions have significant effect on lambs weight traits, because these type of trait classified as a quantification trait which controlled by each genotypic and environmental effect with interaction between them.

The ewe age seems to have no significant effect on all lambs body weight such effect of ewe age on lambs birth and weaning weight are in agreement with some earlier studies (Al-Barzinji, 2003; Jalil-Sarghale et al., 2014; Al-Bial et al., 2016). Similar results of pre-weaning daily gain in different breeds have been noticed by other (Khalaf et al., 2010; Gokdal, et al., 2006). Non significant effect of post-weaning gain due to the age found under the present study was disagreement with that reported by (Baneh and Hafezian, 2009; Marufa et al., 2017).

Male lambs were statistically heavier than females at birth, although, this difference was statistically no significant for other growth traits (Table 1). Similarly, many authors claimed that sex of lamb had no effect on birth and weaning weight of different breeds of sheep (Al-Bial et al., 2016; Siddalingamurthy et al., 2017). Moreover, the findings in this study for pre-weaning daily gain was also in agreement with those previously obtained by Gokdal et al. (2006) and Abbas et al. (2010). Likewise, daily weight gain after weaning stage by sex of lamb observed in the present study was in accordance with reported finding by Marufa et al. (2017). Although average daily gain was heavies for male than female lambs, differences between them lacked significance. Their averages were $0.15 \pm 0.01$ and $0.13 \pm 0.00 \mathrm{~kg}$, respectively.

The month of lambing also influences MW, ADG and post daily gain. Lambs born early in the lambing period (December and January) gained weight better than those born late (February) due to the accessibility to the pastures in spring season. Lambs born late will not be able to use pasture in spring because of their young age besides they may have higher exposure to internal parasites which thrive in the high temperature. Thus, their weaning and yearling weights will be lower than those lambed early (Elwakil et al., 2009). Heaviest lambs at birth and marketing weight were at December, whereas the lighter lamb's birth weight and marketing weight were at February. It is known that month of birth may cause variations in weight and performance of lambs due to climatic variations and/or management (Bathaei and Leroy, 1997). For weight at marketing age, lambs born at December and January were significantly $(\mathrm{p} \leq 0.05)$ heaviest than those lambs born at February. However, results of the present study were similar to those reported earlier claiming that month of lambing was not significantly affect birth weight in different breeds of sheep (Khalaf et al., 2010; Al-Bial et al., 2016) and weaning weight (Mohammed, 2008). The present results for pre-waning daily gain agreed with those reported by Abbas et al. (2010) who reported pre-weaning daily gain from birth to weaning did not significantly affected by month of lambing. The differences among different reports may be due to breed, size of the data set or method of estimation used in different studies, production system, climatic conditions and ecological zones, where sheep farming were practiced. The significant influences of environmental factors on body weight in the present study can be explained in part by differences in environment, feeding, grazing resources, male and female endocrine system, limited uterine space, and inadequate availability of nutrients during pregnancy, maternal effects and maternal ability of dam at different ages (Rashidi et al., 2008). 
Table 1. Least square means $\pm S E(\mathrm{~kg})$ for birth weight, weaning weight, marketing weight, average daily gain, pre-weaning daily gain and post weaning daily gain in Karadi lambs

\begin{tabular}{|c|c|c|c|c|c|c|}
\hline \multirow[b]{2}{*}{ Fixed effects } & \multirow[b]{2}{*}{ Birth weight } & \multirow{2}{*}{$\begin{array}{l}\text { Weaning } \\
\text { weight }\end{array}$} & \multirow{2}{*}{$\begin{array}{c}\text { Marketing } \\
\text { weight }\end{array}$} & \multicolumn{3}{|c|}{ Daily gain } \\
\hline & & & & Average & Pre-weaning & $\begin{array}{c}\text { Post- } \\
\text { weaning }\end{array}$ \\
\hline Overall mean & $4.14 \pm 0.65$ & $16.37 \pm 2.87$ & $23.60 \pm 4.42$ & $0.12 \pm 0.02$ & $0.13 \pm 0.02$ & $0.12 \pm 0.04$ \\
\hline Flock & NS & $*$ & $*$ & $*$ & $*$ & $*$ \\
\hline 1 & $4.34 \pm 0.13^{\mathrm{a}}$ & $15.66 \pm 0.60^{\mathrm{a}}$ & $19.64 \pm 0.93^{\mathrm{a}}$ & $0.10 \pm 0.01^{\mathrm{a}}$ & $0.12 \pm 0.01^{\mathrm{a}}$ & $0.06 \pm 0.01^{\mathrm{a}}$ \\
\hline 2 & $3.66 \pm 0.37^{\mathrm{a}}$ & $19.86 \pm 1.66^{\mathrm{b}}$ & $28.22 \pm 2.58^{b}$ & $0.16 \pm 0.01^{\mathrm{b}}$ & $0.17 \pm 0.01^{\mathrm{b}}$ & $0.13 \pm 0.02^{b}$ \\
\hline 3 & $4.17 \pm 0.22^{\mathrm{a}}$ & $14.80 \pm 1.00^{\mathrm{a}}$ & $29.48 \pm 1.53^{\mathrm{b}}$ & $0.16 \pm 0.00^{\mathrm{b}}$ & $0.11 \pm 0.01^{\mathrm{a}}$ & $0.24 \pm 0.01^{\mathrm{c}}$ \\
\hline Ewes age (year) & $\mathrm{NS}$ & $\mathrm{NS}$ & NS & NS & NS & NS \\
\hline 2.5 & $4.15 \pm 0.19^{\mathrm{a}}$ & $16.49 \pm 0.87^{\mathrm{a}}$ & $25.52 \pm 1.34^{\mathrm{a}}$ & $0.14 \pm 0.01^{\mathrm{a}}$ & $0.13 \pm 0.01^{\mathrm{a}}$ & $0.15 \pm 0.01^{\mathrm{a}}$ \\
\hline 3.5 & $3.95 \pm 0.18^{\mathrm{a}}$ & $16.81 \pm 0.82^{\mathrm{a}}$ & $25.54 \pm 1.26^{\mathrm{a}}$ & $0.14 \pm 0.01^{\mathrm{a}}$ & $0.14 \pm 0.01^{\mathrm{a}}$ & $0.14 \pm 0.01^{\mathrm{a}}$ \\
\hline 4.5 & $3.73 \pm 0.21^{\mathrm{a}}$ & $15.56 \pm 0.93^{\mathrm{a}}$ & $24.01 \pm 1.44^{\mathrm{a}}$ & $0.13 \pm 0.01^{\mathrm{a}}$ & $0.13 \pm 0.01^{\mathrm{a}}$ & $0.14 \pm 0.01^{\mathrm{a}}$ \\
\hline 5.5 & $4.38 \pm 0.27^{\mathrm{a}}$ & $18.24 \pm 1.18^{\mathrm{a}}$ & $28.04 \pm 1.82^{\mathrm{a}}$ & $0.15 \pm 0.01^{\mathrm{a}}$ & $0.15 \pm 0.02^{\mathrm{a}}$ & $0.16 \pm 0.01^{\mathrm{a}}$ \\
\hline Sex of lamb & NS & $\mathrm{NS}$ & NS & NS & NS & $\mathrm{NS}$ \\
\hline Male & $4.20 \pm 0.25^{\mathrm{a}}$ & $18.03 \pm 1.12^{\mathrm{a}}$ & $27.12 \pm 1.73^{\mathrm{a}}$ & $0.15 \pm 0.01^{\mathrm{a}}$ & $0.15 \pm 0.01^{\mathrm{a}}$ & $0.15 \pm 0.01^{\mathrm{a}}$ \\
\hline Female & $3.91 \pm 0.22^{\mathrm{a}}$ & $15.53 \pm 0.97^{\mathrm{a}}$ & $24.44 \pm 1.49^{\mathrm{a}}$ & $0.13 \pm 0.01^{\mathrm{a}}$ & $0.12 \pm 0.01^{\mathrm{a}}$ & $0.14 \pm 0.01^{\mathrm{a}}$ \\
\hline Month of lambing & NS & NS & $*$ & $*$ & NS & $*$ \\
\hline November & $4.06 \pm 0.14^{\mathrm{a}}$ & $15.60 \pm 0.64^{\mathrm{a}}$ & $25.06 \pm 0.99^{\mathrm{ab}}$ & $0.14 \pm 0.01^{\mathrm{ab}}$ & $0.12 \pm 0.01^{\mathrm{a}}$ & $0.15 \pm 0.01^{\mathrm{a}}$ \\
\hline December & $4.35 \pm 0.28^{\mathrm{a}}$ & $16.68 \pm 1.25^{\mathrm{a}}$ & $29.99 \pm 1.92^{\mathrm{a}}$ & $0.17 \pm 0.01^{\mathrm{a}}$ & $0.13 \pm 0.01^{\mathrm{a}}$ & $0.22 \pm 0.02^{\mathrm{b}}$ \\
\hline January & $4.11 \pm 0.28^{\mathrm{a}}$ & $18.06 \pm 1.24^{\mathrm{a}}$ & $27.02 \pm 1.92^{\mathrm{a}}$ & $0.15 \pm 0.01^{\mathrm{a}}$ & $0.15 \pm 0.01^{\mathrm{a}}$ & $0.14 \pm 0.02^{\mathrm{a}}$ \\
\hline February & $3.70 \pm 0.32^{\mathrm{a}}$ & $16.75 \pm 1.40^{\mathrm{a}}$ & $21.04 \pm 2.16^{\mathrm{b}}$ & $0.11 \pm 0.01^{\mathrm{b}}$ & $0.14 \pm 0.01^{\mathrm{a}}$ & $0.07 \pm 0.02^{c}$ \\
\hline
\end{tabular}

Means in the same column for each factor with different letters are significantly $(\mathrm{p} \leq 0.05)$ different from each other. NS: non significant

\section{Milk traits of Karadi ewes}

The least square means \pm SE of to identify the effect of fixed effects on the observed milk production performance recorded such as daily milk yield, total milk yield, protein $\%$ and fat $\%$ are given in Table 2 . The overall means were $0.236 \pm 0.10 \mathrm{~kg} / \mathrm{day}$, $34.07 \pm 5.94 \mathrm{~kg} / \mathrm{day}, 5.33 \pm 0.62 \%$ and $5.30 \pm 12.93 \%$ for DMY, TMY, protein and fat respectively. The average of daily and total milk yield observed in this study were lower than the range reported earlier by several investigators in different breeds of sheep (Oramari, 2009; Abd Allah et al., 2011). However, protein and fat percentage were similar to other studies reported earlier by several investigators in different breeds of sheep (Bendelja et al., 2009; Abd El-Fatah and Awad, 2014).

Flock significantly $(\mathrm{P} \leq 0.05)$ affected milk production traits. Daily milk yield and total milk yield produced by ewes that were in the third flock was higher $(0.312 \pm 0.01$ and $45.59 \pm 2.05 \mathrm{~kg}$ ) than those produced by ewes from first and second flock $(0.220 \pm 0.01,0.211 \pm 0.02$ and $32.32 \pm 1.24,33.45 \pm 3.40 \mathrm{~kg})$ respectively. Many results are in agreement with the significance effect of flock on daily milk yield (Gardi, 2008; Pérez-Cabal et al., 2013). Moreover, similar significance effect of flock on total milk yield was also reported by (Pérez-Cabal et al., 2013; Meraï et al., 2014). 
Table 2. Least square means \pm SE for daily milk yield (DMY), total milk yield (TMY), protein\% and fat $\%$ in Karadi ewes

\begin{tabular}{|c|c|c|c|c|}
\hline Fixed effects & DMY (kg) & TMY (kg) & Protein \% & Fat $\%$ \\
\hline Overall mean & $0.236 \pm 0.10$ & $34.07 \pm 5.94$ & $5.33 \pm 0.62$ & $5.30 \pm 12.93$ \\
\hline Flock & $*$ & $*$ & NS & NS \\
\hline 1 & $0.220 \pm 0.01^{\mathrm{a}}$ & $32.32 \pm 1.24^{\mathrm{a}}$ & $5.33 \pm 0.06^{\mathrm{a}}$ & $4.23 \pm 1.27^{\mathrm{a}}$ \\
\hline 2 & $0.211 \pm 0.02^{\mathrm{a}}$ & $33.45 \pm 3.40^{\mathrm{a}}$ & $5.15 \pm 0.16 \mathrm{a}$ & $6.81 \pm 3.48^{\mathrm{a}}$ \\
\hline 3 & $0.312 \pm 0.01^{\mathrm{b}}$ & $45.59 \pm 2.05^{\mathrm{b}}$ & $5.46 \pm 0.10^{\mathrm{a}}$ & $4.37 \pm 2.09^{\mathrm{a}}$ \\
\hline Ewes age (year) & NS & NS & $\mathrm{NS}$ & NS \\
\hline 2.5 & $0.261 \pm 0.01^{\mathrm{a}}$ & $39.77 \pm 1.79^{\mathrm{a}}$ & $5.37 \pm 0.08^{\mathrm{a}}$ & $5.31 \pm 1.83^{\mathrm{a}}$ \\
\hline 3.5 & $0.245 \pm 0.01^{\mathrm{a}}$ & $36.75 \pm 1.68^{\mathrm{a}}$ & $5.30 \pm 0.08^{a}$ & $6.07 \pm 1.72^{\mathrm{a}}$ \\
\hline 4.5 & $0.241 \pm 0.01^{\mathrm{a}}$ & $35.90 \pm 1.90^{\mathrm{a}}$ & $5.20 \pm 0.09^{\mathrm{a}}$ & $4.71 \pm 1.97^{\mathrm{a}}$ \\
\hline 5.5 & $0.244 \pm 0.01^{\mathrm{a}}$ & $36.06 \pm 2.40^{\mathrm{a}}$ & $5.39 \pm 0.12^{\mathrm{a}}$ & $4.45 \pm 2.48^{\mathrm{a}}$ \\
\hline Sex of lambs & NS & NS & NS & NS \\
\hline Male & $0.251 \pm 0.01^{\mathrm{a}}$ & $37.88 \pm 2.32^{\mathrm{a}}$ & $5.42 \pm 0.11^{\mathrm{a}}$ & $5.37 \pm 2.36^{\mathrm{a}}$ \\
\hline Female & $0.245 \pm 0.01^{\mathrm{a}}$ & $36.36 \pm 2.00^{\mathrm{a}}$ & $5.21 \pm 0.09^{\mathrm{a}}$ & $4.90 \pm 2.02^{\mathrm{a}}$ \\
\hline Month of lambing & NS & NS & $\mathrm{NS}$ & $\mathrm{NS}$ \\
\hline November & $0.247 \pm 0.01^{\mathrm{a}}$ & $34.66 \pm 1.26^{\mathrm{a}}$ & $5.34 \pm 0.06^{\mathrm{a}}$ & $5.26 \pm 1.34^{\mathrm{a}}$ \\
\hline December & $0.264 \pm 0.01^{\mathrm{a}}$ & $39.27 \pm 2.57^{\mathrm{a}}$ & $5.20 \pm 0.12^{\mathrm{a}}$ & $5.58 \pm 2.60^{\mathrm{a}}$ \\
\hline January & $0.246 \pm 0.01^{\mathrm{a}}$ & $37.10 \pm 2.57^{\mathrm{a}}$ & $5.50 \pm 0.12^{\mathrm{a}}$ & $4.98 \pm 2.59^{\mathrm{a}}$ \\
\hline February & $0.234 \pm 0.02^{\mathrm{a}}$ & $37.45 \pm 2.89^{\mathrm{a}}$ & $5.22 \pm 0.14^{\mathrm{a}}$ & $4.72 \pm 2.95^{\mathrm{a}}$ \\
\hline Stage of lactation (month) & $*$ & & $*$ & NS \\
\hline 1 & $0.321 \pm 0.01^{\mathrm{a}}$ & ----- & $5.33 \pm 0.08^{\mathrm{a}}$ & $4.83 \pm 1.83^{\mathrm{a}}$ \\
\hline 2 & $0.339 \pm 0.02^{\mathrm{a}}$ & 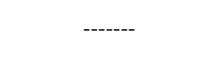 & $5.51 \pm 0.08^{\mathrm{a}}$ & $4.90 \pm 1.84^{\mathrm{a}}$ \\
\hline 3 & $0.281 \pm 0.01^{\mathrm{b}}$ & - & $5.32 \pm 0.08^{\mathrm{a}}$ & $7.62 \pm 1.85^{\mathrm{a}}$ \\
\hline 4 & $0.201 \pm 0.01^{\mathrm{c}}$ & $\ldots-$ & $5.31 \pm 0.08^{\mathrm{a}}$ & $4.96 \pm 1.84^{\mathrm{a}}$ \\
\hline 5 & $0.100 \pm 0.01^{\mathrm{d}}$ & $-\cdots---$ & $4.94 \pm 0.09^{\mathrm{b}}$ & $5.21 \pm 2.10^{\mathrm{a}}$ \\
\hline
\end{tabular}

Means in the same column for each factor with different letters are significantly $(\mathrm{p} \leq 0.05)$ different from each other. NS: non significant

In the present work no significant effect of ewe's age on daily and total milk yield was found, There results were in agreement with those reported earlier by (Merkhan, 2014; Akreyi, 2015). Also, the effect of ewe's age on protein and fat $\%$ lacked significance. Such results were also reported earlier by (Abd Allah et al., 2011; Oramari and Hermiz, 2012). The effect of sex of lamb and month of lambing on the DMY, TMY, protein and fat $\%$ was no significance, these findings were in agreement with those reported on DMY and TMY by (Al-Samarai and Al-Anbari, 2009; Merkhan, 2014 and Akreyi, 2015). Also, an author found that month of lambing had no effect on daily milk yield and total milk yield (Abd-Al-Noor, 2011). Moreover, differences in protein and fat percentage studied in ewes lambed in the four months were not significant (Table 2). In an earlier study in Iraq, Gardi (2008) did not detect a significant effect of month of lambing on protein and fat\% in milk of Karadi, Awassi and Hamdani ewes. Also, Martini et al. (2008) and Augusta et al. (2008) observed no remarkable monthly changes in protein \%. Stage of lactation has significantly $(\mathrm{P} \leq 0.05)$ effected DMY and 
protein\%. Similar results were also obtained by Pavic et al. (2002) and Kuchtik et al. (2008). While stages of lactation had no significant effect on fat\%, which the lowest percentage (4.83) was obtained in the first stage of lactation and highest $(7.62 \%)$ during the $3^{\text {rd }}$ stage of lactation. This result was in agreement with results obtained by Sevi et al. (2006) and Oravcova et al. (2007).

As in Tables 2 and 3 there are variance differences among fixed effect on all traits under studies, it means there are ability to make selection process among sheep to choices the best parents and mated them altogether to speed up the weight and milk traits in the next generation. To removed the effect of fixed factors mixed model was used to calculate the BLUP value which is one methods used to evaluation the animal upon his performances to obtained the realized value for each animals under study to ranking them according to his BLUP values for each trait to select the best one among all animals to speed up the production in next generation.

Table 3 shows the BLUP values for BW, WW, MW, DMY, TMY, protein\% and fat\%. The lowest and highest BLUP value was $(-1.6411$ and $1.6889 \mathrm{~kg})$ for BW, (-6.5307 and 10.1293) for WW, (-9.9775 and 13.1725) for MW, (-10.5293 and 10.7405) for DMY, (-31.02 and 7.38) for TMY, (-2.0546 and 2.0097) for protein\% and $(-1.7033$ and 1.4067) for fat\%, respectively. The wide range between the BLUP values of ewes for some above traits indicated that selection of elite ewe will improve all these traits in the present sample. Hussain et al. (2006) reported that BLUP value for weaning weight ranged from -1.799 to $2.421 \mathrm{~kg} / \mathrm{ewe}$ in Thalli sheep. Al-Barzinji (2009) reported that BLUP values for ewes ranged from -12.338 to $11.6023 \mathrm{~kg}$ for total weight of lambs weaned. In Hamdani sheep predicted BLUP value for daily milk yield from two flocks was reported by Al-Barzinji (2003), from two flocks. Values ranged from -155.56 to $214.58 \mathrm{gm}$ and from -162.46 to $240.39 \mathrm{gm}$ in the two flocks respectively. BLUP values for top $10 \%$ of the ewes to be selected as dam of ram lambs ranged between 102.87 to $214.58 \mathrm{gm}$ and 187.63 to $240.39 \mathrm{gm}$ in first and second flocks, while the values for culling $20 \%$ ranged from -155.56 to $-66.50 \mathrm{gm}$ and from -162.46 to $-98.44 \mathrm{gm}$ for first and second flock, respectively. Al-Rawi et al. (2002b) revealed that BLUP values for total milk yield ranged from -28.29 to $82.61 \mathrm{~kg}$ in Awassi sheep respectively. In Awassi sheep Abdulnoor (2004) reported that BLUP values for total milk yield for selecting 90, $80,70,60$ and $50 \%$ of ewes were $1.98,3.64,5.07,6.62$ and $8.15 \mathrm{~kg}$, respectively. AlBarzinji (2009) reported that BLUP values for total milk yield in ewes ranged from 68.160 to $139.951 \mathrm{~kg}$.

These results show that the breeder can select $10 \%$ from top BLUP value (Male) and $70 \%$ from top BLUP value (Female) and mate these parents altogether can speed up improvement of weight and milk traits among this population of sheep under study. 
Table 3. BLUP values ( $k g$ ) of $B W, W W, M W, D M Y, T M Y$, protein $\%$ and fat $\%$ in Karadi ewes

\begin{tabular}{|c|c|c|c|c|c|c|c|c|c|c|c|c|c|}
\hline $\begin{array}{l}\text { Ewe } \\
\text { No. }\end{array}$ & $\begin{array}{l}\text { BLUP } \\
(\text { BW) }\end{array}$ & \begin{tabular}{|l|} 
Ewe \\
No.
\end{tabular} & $\begin{array}{l}\text { BLUP } \\
(\mathbf{W W}) \\
\end{array}$ & \begin{tabular}{|c} 
Ewe \\
No. \\
\end{tabular} & $\begin{array}{l}\text { BLUP } \\
\text { (MW) }\end{array}$ & $\begin{array}{l}\text { Ewe } \\
\text { No. }\end{array}$ & $\begin{array}{l}\text { BLUP } \\
\text { (DMY) }\end{array}$ & $\begin{array}{l}\text { Ewe } \\
\text { No. }\end{array}$ & \begin{tabular}{|l} 
BLUP \\
(TMY)
\end{tabular} & \begin{tabular}{|l} 
Ewe \\
No.
\end{tabular} & $\begin{array}{c}\text { BLUP } \\
\text { (Protein\%) }\end{array}$ & $\begin{array}{l}\text { Ewe } \\
\text { No. } \\
\end{array}$ & $\begin{array}{l}\text { BLUP } \\
\text { (Fat\%) }\end{array}$ \\
\hline 87 & 1.688 & 55 & 10.12 & 74 & 13.17 & 99 & 10.75 & 51 & 7.380 & 102 & 2.009 & 65 & 1.406 \\
\hline 41 & 1.678 & 74 & & 93 & & 94 & & 102 & & 99 & & 16 & 1.066 \\
\hline 81 & 1.658 & 81 & 9.569 & 81 & 2.42 & 108 & 10.09 & 97 & 1.200 & 106 & 95 & 19 & 1.006 \\
\hline 40 & 1.648 & 80 & 8.219 & 87 & 11.47 & 111 & 9.768 & 111 & 0.480 & 109 & 1.784 & 78 & 1.006 \\
\hline 9 & 1.558 & 63 & 5.919 & 94 & 11.27 & 96 & 9.640 & 114 & 0 & 101 & 1.716 & 70 & 0.996 \\
\hline 43 & 1.138 & 89 & 5.069 & 55 & 10.27 & 106 & 9.359 & 109 & -0.600 & 107 & 1.660 & 15 & 0.956 \\
\hline 73 & 0.958 & 24 & 5.0 & 71 & 10.22 & 91 & & 94 & & 95 & & 20 & 0.956 \\
\hline 39 & 0.878 & 72 & 4.719 & 76 & 10.07 & 104 & 8.417 & 107 & -1.980 & 97 & 1.525 & 27 & 0.956 \\
\hline 1 & 0.808 & 69 & 4.669 & 90 & 9.122 & 105 & 8.090 & 108 & -2.460 & 114 & 1.347 & 37 & 0.956 \\
\hline 74 & 0.808 & 39 & 4.409 & 85 & 9.072 & 98 & 7.517 & 101 & -3.300 & 111 & 1.338 & 12 & 0.916 \\
\hline 37 & 0.778 & 31 & 4.219 & 92 & 8.672 & 107 & 7.272 & 110 & -3.660 & 94 & & 41 & 0.896 \\
\hline 38 & 0.768 & 64 & 4.219 & 72 & 8.472 & 103 & 6.903 & 106 & -4.200 & 108 & & 4 & 0.846 \\
\hline 6 & 0.758 & 71 & 4.219 & 73 & 8.322 & 109 & 6.862 & 112 & -4.260 & 51 & 1.124 & 29 & 0.676 \\
\hline 13 & 0.758 & 59 & 4.019 & 88 & 8.172 & 102 & 6.371 & 105 & -4.980 & 92 & 1.111 & 88 & 0.646 \\
\hline 42 & 0.758 & 73 & 3.969 & 80 & 7.872 & 17 & 6.131 & 88 & -6.360 & 87 & 1.012 & 93 & 0.636 \\
\hline 10 & 0.658 & 60 & 3.889 & 63 & 7.672 & 84 & 6.089 & 98 & -6.420 & 113 & & 1 & 0.596 \\
\hline 85 & 0.658 & 68 & 3.819 & 68 & 7.622 & 85 & 5.430 & 100 & -6.420 & 21 & 0.863 & 31 & 0.516 \\
\hline 55 & 0.628 & 66 & 3.219 & 64 & 7.172 & 95 & 5.389 & 113 & -6.540 & 22 & 0.863 & 32 & 0.516 \\
\hline 93 & 0.618 & 95 & 3.219 & 31 & 6.572 & 97 & 5.389 & 37 & -6.900 & 93 & 0.861 & 34 & 0.516 \\
\hline 45 & 0.608 & 76 & 2.969 & 69 & 5.672 & 110 & 5.307 & 95 & -7.320 & 112 & & 35 & 0.516 \\
\hline 46 & 0.558 & 79 & 2.819 & 41 & 5.422 & 37 & 5.062 & 99 & -7.560 & 110 & & 24 & 0.426 \\
\hline 80 & 0.518 & 38 & 2.469 & 66 & 5.422 & 92 & 4.775 & 92 & -7.860 & 37 & 0.807 & 9 & 0.406 \\
\hline 26 & 0.468 & 47 & 2.469 & 89 & 5.422 & 51 & 4.734 & 13 & -8.640 & 86 & 0 & 13 & 0.406 \\
\hline 25 & 0.458 & 92 & 2.429 & 39 & 5.172 & 89 & 4.407 & 93 & -9.480 & 105 & 0.732 & 76 & 0.406 \\
\hline 82 & 0.458 & 41 & 2.369 & 95 & 4.622 & 13 & 3. & 12 & -9.840 & 47 & & 94 & 0.406 \\
\hline 28 & 0.418 & 56 & 2.109 & 75 & 4.322 & 81 & 3.833 & 86 & -9.960 & 33 & 0.709 & 38 & 0.296 \\
\hline 31 & 0.418 & 15 & 1.519 & 91 & 4.322 & 39 & 3.499 & 47 & -10.29 & 88 & & 30 & 0.246 \\
\hline 44 & 0.408 & 78 & 1.469 & 38 & 4.172 & 90 & 3.302 & 50 & & 39 & & & 0.216 \\
\hline 34 & 0.378 & 87 & 1.469 & 56 & 4.172 & 8 & 3.081 & 34 & -10.80 & 98 & 0.632 & 98 & 0.206 \\
\hline 83 & 0.368 & 65 & 1.419 & 15 & 4.122 & 12 & 3.057 & 85 & -11.22 & 18 & & 23 & 0.176 \\
\hline 5 & 0.358 & 5 & 1.369 & 42 & 3.622 & 83 & 2.975 & 38 & -11.88 & 11 & 0.582 & 62 & 0.176 \\
\hline 60 & 0.358 & 52 & 1.319 & 24 & 3.422 & 47 & 2.750 & 17 & -12.60 & 34 & & 10 & 0.086 \\
\hline 92 & 0.328 & 29 & 1.269 & 86 & 3.372 & 86 & 2.580 & 87 & -12.66 & 100 & & 105 & 0.0667 \\
\hline 103 & 0.288 & 54 & 1.219 & 59 & 2.672 & 42 & 2.454 & 19 & -12.96 & 17 & 0.477 & 1 & 0 \\
\hline 95 & 0.248 & 70 & 1.219 & 67 & 2.672 & 34 & 2.402 & 18 & -13.02 & 89 & & 2 & 0 \\
\hline 23 & 0.208 & 42 & 1.169 & 62 & 2.622 & 82 & 2.115 & 30 & -13.02 & 84 & 0.367 & 3 & 0 \\
\hline 48 & 0.208 & 67 & 1.169 & 78 & 2.272 & 38 & 1.665 & 16 & -13.26 & 8 & 0.270 & 6 & 0 \\
\hline 71 & 0.208 & 82 & 1.169 & 101 & 2.022 & 28 & 950 & 21 & -13.50 & 31 & 224 & 8 & 0 \\
\hline 33 & 0.198 & 46 & 1.069 & 60 & 1.872 & 19 & 0.929 & 22 & -13.50 & 12 & 0.212 & 11 & 0 \\
\hline 24 & 0.178 & 58 & & 6 & 1.472 & 6 & 0.909 & 31 & -13.62 & 42 & 0.168 & 14 & 0 \\
\hline 86 & 0.168 & 62 & 0.919 & 54 & 1.472 & 18 & 0.888 & 33 & -13.62 & 79 & 0.121 & 17 & 0 \\
\hline 97 & 0.168 & 75 & 0.919 & 70 & 1.162 & 30 & 0.888 & 24 & -13.74 & 45 & 0.103 & 18 & 0 \\
\hline 108 & 0.168 & 108 & 0.819 & 108 & 0.772 & 61 & -0.789 & 29 & -13.74 & 61 & -0.185 & 21 & 0 \\
\hline
\end{tabular}




\begin{tabular}{|c|c|c|c|c|c|c|c|c|c|c|c|c|c|}
\hline $\begin{array}{l}\text { Ewe } \\
\text { No. }\end{array}$ & $\begin{array}{c}\text { BLUP } \\
\text { (BW) }\end{array}$ & $\begin{array}{l}\text { Ewe } \\
\text { No. }\end{array}$ & $\begin{array}{l}\text { BLUP } \\
\text { (WW) }\end{array}$ & $\begin{array}{l}\text { Ewe } \\
\text { No. }\end{array}$ & $\begin{array}{l}\text { BLUP } \\
\text { (MW) }\end{array}$ & $\begin{array}{l}\text { Ewe } \\
\text { No. }\end{array}$ & $\begin{array}{l}\text { BLUP } \\
\text { (DMY) }\end{array}$ & \begin{tabular}{|l|} 
Ewe \\
No.
\end{tabular} & $\begin{array}{l}\text { BLUP } \\
\text { (TMY) }\end{array}$ & $\begin{array}{l}\text { Ewe } \\
\text { No. }\end{array}$ & $\begin{array}{c}\text { BLUP } \\
\text { (Protein\%) }\end{array}$ & $\begin{array}{c}\text { Ewe } \\
\text { No. }\end{array}$ & $\begin{array}{l}\text { BLUP } \\
\text { (Fat\%) }\end{array}$ \\
\hline 112 & 0.168 & 112 & -1.010 & 112 & -0.877 & 11 & -0.298 & 45 & -13.80 & 103 & -0.147 & 22 & 0 \\
\hline 114 & 0.168 & 114 & -1.030 & 114 & 0.122 & 9 & -0.789 & 20 & -13.98 & 36 & -0.154 & 25 & 0 \\
\hline 8 & 0.158 & 86 & 0.919 & 100 & 0.872 & 16 & 0.724 & 41 & -14.22 & 6 & 0.084 & 26 & 0 \\
\hline 27 & 0.158 & 6 & 0.819 & 79 & 0.772 & 21 & 0.560 & 46 & -14.58 & 41 & & 28 & 0 \\
\hline 75 & 0.158 & 45 & 0.819 & 29 & 0.372 & 22 & 0.560 & 11 & -14.76 & 16 & 0.058 & 33 & 0 \\
\hline 109 & 0.158 & 109 & 0.819 & 109 & 0.372 & 60 & 0.233 & 15 & -15.36 & 60 & -0.016 & 36 & 0 \\
\hline 77 & 0.138 & 61 & 0.819 & 26 & 0.322 & 31 & 0.478 & 9 & -15.48 & 13 & 0.057 & 39 & 0 \\
\hline 35 & 0.118 & 50 & 0.719 & 58 & 0.322 & 33 & 0.478 & 44 & -15.54 & 20 & 0.042 & 42 & 0 \\
\hline 30 & 0.088 & 101 & 0.719 & 65 & 0.272 & 52 & 0.449 & 83 & -15.78 & 3 & & 48 & 0 \\
\hline 3 & 0.058 & 77 & 0.319 & 23 & 0.222 & 24 & 0.397 & 84 & -15.90 & 19 & -0.016 & 52 & 0 \\
\hline 15 & 0.058 & 96 & 0.169 & 4 & 0.122 & 29 & 0.397 & 23 & -16.08 & 30 & -0.018 & 54 & 0 \\
\hline 47 & 0.058 & 48 & 0.119 & 37 & 0.072 & 45 & 0.356 & 78 & -16.14 & 85 & -0.044 & 56 & 0 \\
\hline 50 & 0.008 & 85 & 0.069 & 82 & 0.072 & 20 & 0.233 & 39 & -16.38 & 50 & & 57 & 0 \\
\hline 89 & -0.011 & 107 & 0.019 & 107 & -0.027 & 41 & 0.069 & 40 & -16.38 & 28 & -0.120 & 59 & 0 \\
\hline 59 & -0.021 & 49 & -0.280 & 96 & -0.127 & 44 & -0.830 & 27 & -16.56 & 83 & -0.182 & 60 & 0 \\
\hline 98 & -0.021 & 91 & -0.530 & 98 & -0.327 & 25 & -0.845 & 79 & -16.62 & 104 & -0.185 & 61 & 0 \\
\hline 29 & -0.031 & 27 & -0.580 & 99 & -0.427 & 64 & -0.845 & 32 & -16.80 & 96 & -0.190 & 63 & 0 \\
\hline 7 & -0.041 & 97 & -0.580 & 43 & -0.627 & 80 & -0.994 & 8 & -16.98 & 57 & -0.198 & 7 & 0 \\
\hline 19 & -0.041 & 13 & -0.630 & 40 & -0.877 & 50 & -1.157 & 10 & -17.04 & 25 & -0.210 & 68 & 0 \\
\hline 101 & -0.061 & 83 & -0.680 & 61 & -0.877 & 23 & -1.199 & 36 & -17.52 & 29 & -0.213 & 69 & 0 \\
\hline 94 & -0.081 & 2 & -0.730 & 77 & -0.877 & 75 & -1.239 & 76 & -17.52 & 24 & -0.283 & 64 & 0 \\
\hline 2 & -0.091 & 94 & -0.730 & 97 & -0.927 & 40 & -1.403 & 43 & -17.58 & 78 & -0.297 & 73 & 0 \\
\hline 54 & -0.091 & 100 & -0.730 & 13 & -0.977 & 27 & -1.526 & 89 & -17.70 & 67 & -0.307 & 80 & 0 \\
\hline 69 & -0.091 & 57 & -0.750 & 106 & -1.427 & 76 & -1.567 & 42 & -17.88 & 76 & -0.329 & 75 & 0 \\
\hline 79 & -0.101 & 44 & -0.830 & 2 & -1.477 & 32 & -1.690 & 96 & -17.88 & 27 & -0.341 & 77 & 0 \\
\hline 88 & -0.101 & 1 & -0.930 & 1 & -1.727 & 14 & -1.799 & 49 & -18.27 & 38 & -0.348 & 79 & 0 \\
\hline 90 & -0.101 & 93 & -1.010 & 57 & -1.727 & 10 & -1.853 & 62 & -18.48 & 48 & -0.349 & 82 & 0 \\
\hline 111 & -0.101 & 111 & -0.630 & 111 & 0.122 & 46 & -0.175 & 74 & -18.48 & 52 & -0.130 & 71 & 0 \\
\hline 4 & -0.141 & 88 & -1.030 & 103 & -1.727 & 61 & -2.015 & 35 & -18.57 & 15 & -0.381 & 72 & 0 \\
\hline 12 & -0.141 & 12 & -1.430 & 12 & -1.927 & 53 & -2.222 & 73 & -18.72 & 91 & -0.394 & 84 & 0 \\
\hline 20 & -0.141 & 37 & -1.130 & 105 & -1.727 & 36 & -2.181 & 7 & -18.78 & 82 & -0.382 & 86 & 0 \\
\hline 49 & -0.141 & 23 & -1.380 & 5 & -1.927 & 73 & -2.181 & 54 & -19.50 & 40 & -0.382 & 87 & 0 \\
\hline 53 & -0.141 & 26 & -1.430 & 34 & -1.927 & 43 & -2.222 & 65 & -19.74 & 56 & -0.394 & 90 & 0 \\
\hline 96 & -0.141 & 90 & -1.430 & 27 & -1.977 & 87 & -2.307 & 103 & -19.74 & 46 & -0.407 & 95 & 0 \\
\hline 110 & -0.141 & 110 & -0.580 & 110 & -0.877 & 59 & -0.830 & 57 & -19.86 & 59 & -0.190 & 99 & 0 \\
\hline 113 & -0.141 & 113 & 0.819 & 113 & -1.727 & 15 & -0.707 & 82 & -19.86 & 1 & -0.150 & 101 & 0 \\
\hline 100 & -0.161 & 10 & -1.580 & 102 & -2.377 & 3 & -2.349 & 28 & -20.04 & 75 & -0.419 & 103 & 0 \\
\hline 52 & -0.241 & 98 & -1.780 & 83 & -3.177 & 93 & -2.426 & 6 & -20.10 & 44 & -0.419 & 104 & 0 \\
\hline 91 & -0.251 & 11 & -1.880 & 47 & -3.427 & 49 & -2.692 & 58 & -20.10 & 73 & -0.427 & 106 & 0 \\
\hline 107 & -0.261 & 43 & -1.930 & 30 & -3.477 & 59 & -2.835 & 60 & -20.11 & 32 & -0.443 & 107 & 0 \\
\hline 72 & -0.301 & 105 & -2.080 & 21 & -3.727 & 71 & -2.835 & 59 & -20.12 & 69 & -0.459 & 113 & 0 \\
\hline 36 & -0.321 & 28 & -2.230 & 28 & -3.877 & 35 & -2.897 & 104 & -20.52 & 71 & -0.475 & 111 & -0.033 \\
\hline 11 & -0.341 & 40 & -2.230 & 19 & -4.127 & 70 & -2.999 & 52 & -20.76 & 49 & -0.507 & 83 & -0.043 \\
\hline 99 & -0.361 & 21 & -2.430 & 11 & -4.327 & 7 & -3.040 & 75 & -21.12 & 54 & -0.514 & 109 & -0.043 \\
\hline 21 & -0.391 & 19 & -2.830 & 52 & -4.427 & 54 & -3.531 & 56 & -21.30 & 68 & -0.517 & 66 & -0.083 \\
\hline
\end{tabular}




\begin{tabular}{|c|c|c|c|c|c|c|c|c|c|c|c|c|c|}
\hline $\begin{array}{c}\text { Ewe } \\
\text { No. }\end{array}$ & $\begin{array}{c}\text { BLUP } \\
\text { (BW) }\end{array}$ & $\begin{array}{l}\text { Ewe } \\
\text { No. }\end{array}$ & $\begin{array}{l}\text { BLUP } \\
(\mathbf{W W})\end{array}$ & $\begin{array}{l}\text { Ewe } \\
\text { No. }\end{array}$ & $\begin{array}{l}\text { BLUP } \\
\text { (MW) }\end{array}$ & $\begin{array}{l}\text { Ewe } \\
\text { No. }\end{array}$ & $\begin{array}{l}\text { BLUP } \\
\text { (DMY) }\end{array}$ & $\begin{array}{c}\text { Ewe } \\
\text { No. }\end{array}$ & $\begin{array}{l}\text { BLUP } \\
\text { (TMY) }\end{array}$ & $\begin{array}{l}\text { Ewe } \\
\text { No. }\end{array}$ & $\begin{array}{c}\text { BLUP } \\
\text { (Protein\%) }\end{array}$ & $\begin{array}{l}\text { Ewe } \\
\text { No. }\end{array}$ & $\begin{array}{l}\text { BLUP } \\
\text { (Fat\%) }\end{array}$ \\
\hline 104 & .391 & 99 & .830 & 25 & -4.477 & 62 & -3.695 & 66 & -21.48 & 14 & -0.562 & 55 & -0.213 \\
\hline 56 & -0.441 & 106 & .830 & 20 & -4.527 & 100 & -3.695 & 62 & -21.48 & 62 & -0.606 & 50 & -0.263 \\
\hline 65 & -0.491 & 30 & -2.980 & 46 & -4.527 & 57 & -3.777 & 48 & -21.54 & 65 & -0.621 & 91 & -0.373 \\
\hline 70 & -0.491 & 53 & -2.980 & 35 & -4.577 & 79 & & 71 & -21.96 & 9 & & 102 & -0.413 \\
\hline 64 & -0.511 & 34 & -3.080 & 36 & -4.627 & 58 & -3.940 & 5 & -22.20 & 10 & & 44 & -0.463 \\
\hline 22 & -0.541 & 36 & -3.130 & 3 & -4.977 & 1 & .145 & 25 & -22.62 & 23 & -0.67 & 112 & -0.463 \\
\hline 57 & -0.541 & 103 & -3.280 & 50 & -5.027 & 101 & -4.227 & 55 & -22.62 & 64 & -0.676 & 108 & -0.473 \\
\hline 105 & -0.541 & 102 & -3.380 & 45 & -5.127 & 65 & -4.521 & 67 & -22.62 & 26 & & $r$ & -0.483 \\
\hline 102 & -0.601 & 18 & -3.430 & 10 & -5.377 & 72 & -4.636 & 81 & -22.86 & 74 & -0.702 & 97 & -0.483 \\
\hline 76 & -0.631 & 25 & -3.480 & 104 & -5.677 & 56 & & 77 & -22.92 & 72 & & 40 & -0.593 \\
\hline 51 & -0.641 & 4 & -3.530 & 33 & -5.877 & 63 & -4.882 & 90 & -23.22 & 77 & -0.832 & 85 & -0.593 \\
\hline 16 & -0.741 & 20 & -3.580 & 48 & -6.327 & 48 & & 70 & -23.94 & 35 & 355 & 4 & -0.683 \\
\hline 106 & -0.761 & 104 & -3.580 & 53 & -6.527 & 68 & -5.209 & 64 & -24.30 & 90 & -0.864 & 49 & -0.703 \\
\hline 84 & -0.831 & 51 & -3.980 & 32 & -6.877 & 5 & & 3 & -24.78 & 80 & 921 & 46 & -0.773 \\
\hline 14 & -0.891 & 9 & -4.380 & 16 & -6.977 & 55 & & 72 & -24.93 & 43 & -1.055 & 114 & -0.783 \\
\hline 63 & -0.901 & 3 & -4.480 & 14 & -7.277 & 78 & -5.823 & 2 & -25.20 & 2 & -1.057 & 53 & -0.793 \\
\hline 62 & -0.911 & 35 & -4.480 & 51 & -7.327 & 74 & & 69 & -26.82 & 66 & & 92 & -0.793 \\
\hline 78 & -0.921 & 16 & -4.530 & 84 & -7.527 & 60 & -6.485 & 1 & -27.36 & 58 & -1.070 & 51 & -0.933 \\
\hline 66 & -0.931 & 17 & -4.930 & 8 & -7.577 & 67 & -6.559 & 4 & -27.72 & 5 & -1.123 & 110 & -0.933 \\
\hline 67 & -0.981 & 14 & -4.980 & 49 & -7.727 & 69 & -7.23 & 68 & -27.90 & 7 & -1.199 & 58 & -1.053 \\
\hline 61 & -1.001 & 8 & -5.030 & 7 & -7.877 & 2 & -7.419 & 80 & -28.38 & 81 & -1.250 & 47 & -1.073 \\
\hline 32 & -1.121 & 33 & -5.130 & 22 & -7.977 & 66 & -8.524 & 91 & -29.76 & 70 & -1.276 & 100 & -1.093 \\
\hline 17 & -1.141 & 7 & -5.530 & 18 & -8.527 & 26 & -8.908 & 63 & -30.72 & 55 & -1.386 & 96 & -1.103 \\
\hline 18 & -1.291 & 84 & -5.630 & 44 & -8.877 & 4 & -9.137 & 53 & -30.78 & 63 & -1.469 & 43 & -1.113 \\
\hline 68 & -1.321 & 32 & -6.080 & 9 & -9.277 & 77 & & 14 & -31.02 & 4 & & 45 & -1.593 \\
\hline 58 & -1.641 & 22 & -6.530 & 17 & -9.977 & 88 & -10.52 & 26 & -34.20 & 53 & -2.054 & 89 & -1.703 \\
\hline
\end{tabular}

\section{Conclusion}

In conclusion, some of the fixed effects including the flock and the Month of lambing affect lamb's body weights significantly, as well as, it appears that flock had a significant influence on daily milk yield and total milk yield and stage of lactation affects test-day milk yield as well as protein percentage significantly. The wide range between the BLUP values of ewes for many growth and milk traits and this indicate that selecting ewes according to their records at early ages will improve their later performance. The recording of data in sheep breeding from breeder side is necessary because the availability of large data and information's on animal's gives better and accurate values for animal evaluation in selection process and breeder must select his animals upon the accurate and analyzed data which obtained from good managements.

\section{REFERENCES}

[1] Abbas, S. F., Abd Allah, M., Allam, F. M., Abooul-Ella, A. A. (2010): Growth performance of Rahmni and Chios lambs weaned at different ages. - Australian Journal Basic \& Applied Science 4: 1583-1589. 
[2] Abd Allah, M., Abass, S. F., Allam, F. M. (2011): Factors affecting the milk yield and composition of Rahmani and Chios sheep. - International Journal of Livestock Production 2(3): 024-030.

[3] Abd El-Fatah, E. N., Awad, E. I. (2014): Bacterial pathogens and somatic cell count in sheep and goat milk. - Journal of Global Biosciences 3(7): 1034-1045.

[4] Abd-Al-Noor, M. J. M. (2011): Some factors effect in milk production and lactation period in local Awassi and Turkish sheep. - Diyala Agricultural Sciences Journal 3(1): 21-29.

[5] Abdulnoor, M. J. (2004): Effect of various selection intensities, based on milk and total lambs' weight weaned of Awassi ewes. - MSc. Thesis, Almusauab Technical College, Iraq.

[6] Ahmad, A. (2011): Animal Production and Veterinary Directorate. - September $8^{\text {th }}$, 18:23. www.NNA.com.

[7] Akreyi, I. A. I. (2015): Udder measurements of Karadi and Awassi sheep and their relation with milk production under local farm conditions. - MSc. Thesis, Coll. of Agric., Univ. of Duhok, Iraq.

[8] Al-Barzinji, Y. M. (2003): A study of growth and body dimensions of lambs and genetic evaluation for milk production of Hamdani ewes. - MSc. Thesis, Salahaddin University, Iraq.

[9] Al-Barzinji, Y. M. (2009): A study of some economical traits with breeding value in Hamdani sheep using molecular genetics techniques. - PhD Dissertation. Animal Resources Department, College of Agriculture, University of Salahaddin, Iraq.

[10] Al-Barzinji, Y. M., Hassan, M. W. (2005): Study of non-genetic factors affecting milk yield and estimation heritability for milk yield in Hamdani ewes. - Iraqi J. Agri. Sci. 7(2): 25-30.

[11] Al-Bial, A., Alazazie, S., Shami, A., Aldoss, A. (2016): Genetic analysis of growth traits in white Boni sheep under the Central Highlands region of Yemen. - Journal of Basic and Applied Research 2(4): 408-413.

[12] Alkass, J. E., Juma, K. H. (2005): Small Ruminant Breeds of Iraq. (Edi. Lusi Iniguez). Characterization of Small Ruminant Breeds in West Asia and North Africa. - ICARDA (International Center of Agriculture Research in the Dry Areas), Aleppo.

[13] Al-Rawi, A. A., Salman, A. D., Al-Azzawi, W. A., Ibraim, S. S. (2002b): breeding values and genetic response of lambs weight weaned and milk yield for Awassi ewes. - IPAJ Agric. Res. 12(3): 67-79.

[14] Al-Samarai, F. R., Al-Anbari, N. N. (2009): Genetic evaluation of rams for total milk yield in Iraqi Awassi sheep. - ARPN Journal of Agricultural and Biological Science 4(3): 54-57.

[15] Al-Samarai, F. R., Mohammed, F. A., Al-Zaydi, F. H., Al-Anbari, N. N., Abdulrahman, Y. K. (2016): Genetic evaluation of Iraqi Awassi rams for some growth traits of their lambs. - American Journal of Applied Scientific Research 2(1): 1-5.

[16] Antonič, J., Jackuliaková, L., Uhrinčat', M., Mačuhová, L., Oravcová, M., Tančin, V. (2013): Changes in milk yield and composition after lamb weaning and start of machine milking in dairy ewes. - Slovak Journal of Animal Science 46: 93-99.

[17] Augusta, L., Vioara, M., Camella, R., Daniela, L. (2008): Seasonal variation of Turcana sheep milk chemical composition. - Lucrari Stiintifice Zootehnie si Biotehnologii 41(2): 758-761.

[18] Baneh, H., Hafezian, S. H. (2009): Effects of environmental factors on growth traits in Ghezel sheep. - African Journal of Biotechnology 8: 2903-2907.

[19] Baneh, H., Hafezian. S. H., Rashidi, A., Gholizadeh, M., Rahimi, G. (2010): Estimation of genetic parameters of body weight traits in Ghezel sheep. - Asian-Aust. J. Anim. Sci. 23(2): 149-153. 
[20] Bathaei, S. S., Leroy, P. L. (1997): Genetic and phenotypic aspects of the curve characteristics in Mehraban Iranian fat-tailed sheep. - Small Ruminant Research 29(3): 261-269.

[21] Bendelja, D., Antunac, N., Milkulec, N., Vnucec, I. (2009): Urea concentration in sheep's milk. - Mljekarstvo 59(1): 3-10.

[22] Cardellino, R. A., Benson, M. E. (2002): Lactation curves of commercial ewes rearing lambs. - J. Anim. Sci. 80: 23-27.

[23] Elwakil, S. L., ElSayed, M., Ahmed, A. M., Sadek, R. R., Nigm, A. A. (2009): Genetic and phenotypic parameters of birth, weaning and yearling body weights of Barki sheep raised in the North West coast of Egypt. - Egyptian J. Anim. Prod. 46: 43-52.

[24] Everett-Hincks, M. J., Mathias-Davis, H. C., Greer, G. J., Auvray, B. A., Dodds, K. G. (2014): Genetic parameters for lamb birth weight, survival and death risk traits. - J. Anim. Sci. 92: 2885-2895.

[25] Gardi, H. E. A. (2008): Effect of Breed and some environmental fixed factors on milk yield in commercial flocks. - MSc. Thesis, College of Agriculture, University of Sallahaddin, Iraq.

[26] Gokdal, O., Ulker, H., Karakus, F., Cengiz, F. (2006): The growth of Karakas and its crosses lambs (F1) with Ile De France X Akkaraman (G1) under unlimited suckling regime. - Journal of Biology Sci. 6(4): 787-792.

[27] Hussain, P., Akhtar, S. A., Younas, M., Shafiq, M. (2006): Effect of inbreeding on preweaning growth traits in Thalli sheep. - Pakistan Vet. J. 26(3): 138-140.

[28] ICARDA, FAO (1995): The Recording of Fat-Tailed Sheep in Syria, Turkey and Jordan. - Consultancy Report, Jordan.

[29] Jalil-Sarghale, A., Kholghi, M., Shahrebabak, M. M., Shahrebabak, H. M., Mohammadi, H., Abdollahi-Arpanah, R. (2014): Model comparisons and genetic parameter estimates of growth traits in Baluchi sheep. - Slovak J. Anim. Sci. 47(1): 12-18.

[30] Jawasreh, K. I. Z., Khasawneh, A. Z. (2007): Studies of some economic characteristics on Awassi lambs in Jordan. - Egyptian Journal of sheep, Goat and Desert Animals Sciences 2(2): 101-110.

[31] Khalaf, A. I., Said, S. I., Edriss, S. M. (2010): Role of some genetic and environmental factors in growth traits of Turkish Awassi, local and crossbred lambs. - The Iraqi Journal of Agricultural Sciences 41(3): 12-22.

[32] Komprej, A., Gorjanc, G., Kompan, D., Kovač, M. (2012): Lactation curves for milk yield, fat, and protein content in Slovenian dairy sheep. - Czech J. Anim. Sci. 57(5): 231239.

[33] Kuchtik, J., Sustova, K., Urban, T., Zapletal, D. (2008): Effect of the stage of lactation on milk composition, its properties and the quality of rennet curdling in East Friesian ewes. Czech J. Anim. Sci. 53: 55-63.

[34] Malik, Z. S., Dalal, D. S., Dahiya, S. P., Patil, C. S., Dahiya, R. (2016): Genetic analysis of growth traits in Harnali sheep. - Veterinary World 9(2): 128-132.

[35] Martini, M., Mele, M., Scolozzi, C., Salari, F. (2008): Cheese making aptitude and chemical and nutritional characteristics of milk from Massese ewes. - Ital. J. Anim. Sci. 7: 419-437.

[36] Marufa, E., Taye, M., Abebe, G., Tera, A., Jimma, A. (2017): Effect of non-genetic factors on reproductive and growth performance of Abera sheep under community based breeding program in SNNPRS Ethiopia. - J Adv Dairy Res 5: 196. DOI: 10.4172/2329888X.1000196.

[37] Meraï, A., Gengler, N., Hammami, H., Rekik, M., Bastin, C. (2014): Non-genetic sources of variation of milk production and reproduction and interactions between both classes of traits in Sicilo-Sarde dairy sheep. - Animal 8(9): 1534-1539.

[38] Merkhan, K. Y. (2014): Milk traits and their relationship with udder measurements in Awassi ewes. - Iranian Journal of Applied Animal Science 4(3): 521-526. 
[39] Mohammed, L. T. (2008): Computing adjustment factors for growth traits in Karadi sheep. - MSc. Thesis, College of Agriculture, University of Duhok, Iraq.

[40] Mousa, M. T., Shetaewi, M. M. (1994): Crossing local Ossimi sheep with imported Chios to improve milk production and pre-weaning lamb gains. - Assuit Vet. Med. J. 30(600): 76-86.

[41] Oramari, R., Hermiz, H. (2012): Non-genetic factors and estimates of repeatability for milk yield traits and compositions in Karadi sheep. - Journal of University of Duhok 15(1): 163-171.

[42] Oramari, R. A. S. (2009): Genetic evaluation of Karadi sheep using some productive traits. - PhD Dissertation. Animal Production Department, College of Agriculture, University of Duhok. Iraq.

[43] Oravcova, M., Margetin, M., Peskovicova, D., Dano, J., Milerski, M., Hetenyi, L., Polak, P. (2007): Factors affecting ewes milk fat and protein content and relationships between milk yield and milk components. - Czech. J. Anim. Sci. 52(7): 189-198.

[44] Pavic, V., Antunac, N., Mioc, B., Ivankovic, A., Havranek, J. L. (2002): Influence of stage of lactation on the chemical composition and physical properties of sheep milk. Czech, J. Anim. Sci. 47(2): 80-84.

[45] Pérez-Cabal, M. Á., Legaz, E., Cervantes, I., de la Fuente, L. F., Martínez, R., Goyache, F., Gutiérrez, J. P. (2013): Association between body and udder morphological traits and dairy performance in Spanish Assaf sheep. - Archiv Tierzucht 56(42): 430-442.

[46] Rahimi, S. M., Rafat, S. A., Jafari, S. (2014): Effects of environmental factors on growth traits in Makuie sheep. - Biotechnology in Animal Husbandry 30(2): 185-192.

[47] Ramakrishanappa, N., Sreesujatha, R. M., Kumar, S. N., Manju, G. U., Roopa Devi, Y. S. (2015): Growth performance of Mandya lambs under farm management. - Indian Vet. J. 92(10): 30-32.

[48] Rashidi, A., Mokhtari, M. S., Jahanshahi, A. S., Mohammad-Abadi, M. R. (2008): Genetic parameter estimates of pre-weaning growth traits in Kermani sheep. - Small Rumin. Res. 7(4): 165-171.

[49] SAS (2010): Statistical Analysis System. Version 9.1. - SAS Institute Inc., Cary, NC.

[50] Sevi, A., Albenzio, M., Annicchiarico, G., Caroprese, M., Marino, R., Santillo, A. (2006): Effects of dietary protein level on ewe milk yield and nitrogen utilization, and on air quality under different ventilation rates. - J. Dairy Res. 73: 197-206.

[51] Sezenler, T., Ceyhan, A., Yükse, M. A., Koncagül, S., Soysal, M., Yildirir, M. (2016): Influence of year, parity and birth type on milk yield and milk components of Bandirma Sheep (German Black Head Mutton x Kıvircık). - Journal of Agricultural Sciences 22: 89-98.

[52] Siddalingamurthy, H. K., Manju, G. U., Roopa Devi, Y. S., Manjunatha, S. S., Sreesujatha, R. M. (2017): Non-genetic factors affecting birth and weaning weight in Mandya sheep. - Int. J. Adv. Res. 5(4): 345-348.

[53] Tariq, M. M., Bajwa, M. A., Babar, S., Waheed, A., Bukhari, F. A., Hameed, T., Marghazani, I. B., Javed, Y. (2011): Effect of non-genetic and genetic factors on birth weight of Mengali sheep of Balochistan. - Can. J. App. Sci. 1(3): 121-128.

[54] Tariq, M. M., Bajwa, M. A., Javed, K., Waheed, A., Awan, M. A., Rafeeq, M., Rashid, N., Shafee, M. (2013): Identification of environmental factors affecting pre weaning performance of Mengali sheep of Balochistan. - Journal of Animal \& Plant Sciences 23(2): 340-344. 